\title{
The Phytochemical Constituents, Analgesic and Anti-inflammatory effects of methanol extract of Jatropha curcas leaves in Mice and Wister albino rats.
}

\author{
${ }^{1} \mathrm{UCHE}, \mathrm{F}$ I; ${ }^{2}$ APRIOKU, J.S
}

\author{
${ }^{1}$ Department of Pharmacognosy and Ethnotherapy Universitty of Port Harcourt \\ ${ }^{2}$ Department of Pharmacology University of Port Harcourt Rivers state Nigeria. \\ Email: uchefideliaijeoma@yahoo.com.+2348037066891
}

\begin{abstract}
The analgesic and anti-inflammatory effects of the methanolic extract of the leaves of Jatropha curcas were investigated in mice and rats respectively. The phytochemical screening of the extract was also carried out. The analgesic effect was determined by acetic acid - induced writhing test in mice. While the anti- inflammatory activity was determined by egg albumin - induced oedema of the rat paw. Phytochemical screening was done by standard procedures. Jatropha curcas leaf extract $(10-80 \mathrm{mg} / \mathrm{kg})$ caused a statistically significant inhibition on the egg albumin - induced eodema or inflammation in Wister albino rats with $\mathrm{P}<0.001$ (ANOVA). This effect was comparable to the observed effect with Piroxicam $(0.5 \mathrm{mg} / \mathrm{kg})$ which was used as a standard. The effect was also dose- dependent. Furthermore, Jatropha curcas extract caused a statistically significant reduction in the number of acetic acid- induced writhing in mice, with $\mathrm{P}<0.001$ (ANOVA). These effects were also dose- dependent and comparable to the analgesic effects obtained with paracetamol which was used as a reference drug. Phytochemical screening revealed the presence of Flavonoids, steroids, triterpenoids Alkaloids, tannins and saponins in Jatropha curcas leaf extract. Jatropha curcas can be recommended for acute inflammatory disorders and diseases associated with pains. This also supports its use traditionally as an anti-snake bite, rheumatism and anti- cancer or anti-tumor agent. Further study is on the way to find out the mechanism of its action and also to isolate, identify and characterize the active agent responsible for these effects in this plant. @ JASEM
\end{abstract}

Jatropha curcas or Physic nut is a multipurpose and drought resistant, perennial plant belonging to the family Euphorbiaceae (Jones and Miller 1992; Openshaw, 1986). It is a tropical plant that can be grown in low to high rainfall areas either in the farm as a commercial crop or on the boundaries as a hedge to protect fields from grazing animals and to prevent erosion (Henry, 1996; Gubitz 1997). The leaves are remedy for jaundice, applied by rectal injection (Okujagu et al.,2006). In India the latex of the stem is mixed with salt to clean teeth. The roots are used for treating chest disease or may be cooked with gruel and given to patients suffering from kidney diseases (Okujagu et al., 2006). The by-products are press cake; good organic fertilizer oil contains also insecticides (Openshaw, 1986). The oil has a strong purgative action and is also widely used for skin diseases and to soothe pain such as that caused by rheumatism (Okujagu et al., 2006). The oil burns with clear smoke free flame, tested successfully as fuel for simple diesel engine (Gubitz 1997). Traditionally it is used to cure diseases like cancer, piles, snakes bites, paralysis, dropsy (Okujagu et al., 2006). However, limited information is available on the pharmacological properties of this plant. There is no scientific report on the analgesic and antiinflammatory effects of this plant to the best of our knowledge, while there are claims on its use traditionally for treatment of Snake- bite and cancer or tumor. Based on these claims, this study seeks to investigate and establish a scientific report on the analgesic and anti-inflammatory effects of this plant.

\section{MATERIALS AND METHOD}

Plant materials: The fresh leaves of Jatropha curcas were collected in October, 2007, from the local garden within the premises of University of Port Harcourt Nigeria. The plant materials were taxonomically identified by H.D. Onyeachusim of Botany Herbarium, University of Port Harcourt where Voucher specimen was deposited. The leaves were air- dried until a constant weight was obtained (10 days).

Extraction: The dried leaves were pulverized to fine powder and extracted with methanol in a Soxhlet extraction apparatus. The solvent was removed under reduced pressure and semi-solid mass obtained concentrated by vacuum drying to yield a solid residue. This was kept in refrigerator for phytochemical and bioassay.

\begin{abstract}
Animals
Male Wister albino rats of weight range 160- $210 \mathrm{~g}$ and male Swiss albino mice of weight range $35-45 \mathrm{~g}$ were used in this study. The animals were obtained from animal house of University of Port Harcourt. They were grouped and housed in a cage of five animals per cage and allowed to acclimatize with the new environment for 10 days. They were maintained under standard laboratory conditions. The animals were allowed free access to standard dry pellet diet and given water ad libitum.
\end{abstract}

All chemicals used are of analar grade. 


\section{Phytochemical screening}

Chemical tests were carried out on the methanolic extracts and on the powdered specimens using standard procedures to identify the constituents (Trease and Evans, 1989; Harborne, 1998) by characteristic colour changes as described by Sofowara, (1993); Odebedy and Sofowara, (1978).

Anti- inflammatory activity: Egg albumin-induced rat paw oedema0

Six groups of rats, each was administered either plant extract $(10,20,40$ 0r $80 \mathrm{mg} / \mathrm{kg}$ i.p), Piroxicam $(0.5 \mathrm{mg} / \mathrm{kg}$ i.p) or normal saline as control $(0.5 \mathrm{ml} / \mathrm{kg})$ 1 hour before the induction of inflammation. Acute inflammation was produced by the sub-planter administration of $0.1 \mathrm{ml}$ fresh egg albumin into the right hind paw of each rat 1 hour after administration of respective extracts. The paw volume was measured at $0 \mathrm{~min}$ and $180 \mathrm{mins}$, taking the readings at 20mins intervals, after the egg- albumin administration by displacement technique using digital Phlethysmometer (Akah and Nnambie, 1994).

The average volume of the right hind paw of each rat was calculated from four readings which did not deviate more than 3\% (Ascongelem et al., 2004). The anti-inflammatory effects of the extract was calculated by the following equation:

Anti-inflammatory activity $(\%)=(1-D / C) \times 100$ Where $\mathrm{D}$ represent the percentage difference in paw volume after extract administration and $\mathrm{C}$ the percentage difference in volume of the control group (Gupta et al., 2005).

\section{Analgesic Activity: Acetic acid induced writhing response in Mice}

Analgesic effects of the plant extracts were evaluated by Veerappan et al., (2005)

Method with little modification. Six groups of five mice each were administered normal saline $(0.5 \mathrm{ml} / \mathrm{kg}$ i.p), as control, paracetamol (100mg/kg i.p) or extract $(10,20,40.80 \mathrm{mg} / \mathrm{kg}$ i.p). I hour later, $0.6 \%$ acetic acid $(10 \mathrm{ml} / \mathrm{kg}) \quad$ solution was administered intraperitoneally to all the animals in different groups. The number of writhes occurring between 5 and 20mins after acetic acid injection was counted. A significant reduction of writhes in tested animals compared to control group was considered as an antinociceptic response.

\section{Statistical analysis}

Values were expressed as mean $\pm \operatorname{SEM}(n=5)$. Statistical analysis was carried out using Graph Pad prism demo software. One way analysis of variance (ANOVA) was used. Values of $\mathrm{P}<0.05$ were considered significant.

\section{RESULTS AND DISCUSSION}

In anti-inflammatory activity test, Jatropha curcas extract $(10-80 \mathrm{mg} / \mathrm{kg})$ caused statistically significant $(\mathrm{P}<0.001$ ANOVA) inhibition of inflammation induced by egg albumin in the rats paw. The percentage inhibition of the inflammation caused by the Jatropha curcas extract $(10-80 \mathrm{mg} / \mathrm{kg})$ was comparable to that obtained with Piroxicam $(0.5 \mathrm{mg} / \mathrm{kg})$ which was used as standard (figure 1). These were also dose- dependent.

In acetic acid - induced writhing test in mice, Jatropha curcas $(10-80 \mathrm{mg} / \mathrm{kg})$ caused statistically significant $(\mathrm{P}<0.001$, ANOVA) reduction in the mean number of writhes induced by acetic acid (figure 2). The number of writhes reduced from 60.0 \pm 3.40 , observed with the group administered normal saline to $28.0 \pm 1.20$ in group administered paracetamol used as standard. Jatropha curcas (10- 80mg/kg)induced reduction in the mean number of writhes was comparable to that observed with Paracetamol which was used as a standard (figure 2). These effects were also dose- dependent.

The phytochemical screening indicated the presence of Alkaloids, flavonoids, terpenoids, saponins, and tannins in the Jatropha curcas leaves (table1)

Table 1: Phytochemiacal Screening

\begin{tabular}{ll}
\hline Phytochemicals & Jatropha curcas \\
\hline Alkaloids & + \\
Flavonoids & + \\
Terpenoids & + \\
Saponins & + \\
Tannins & + \\
Steroids & + \\
Resins & - \\
\hline Volatile oils & + \\
\hline$+=$ present & \\
$-=$ absent &
\end{tabular}




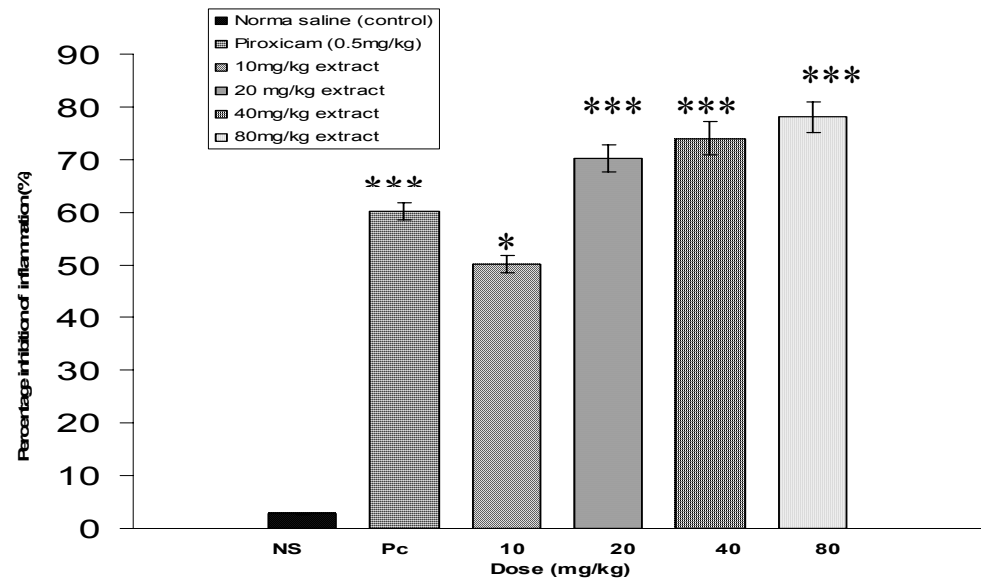

Figure 1: The Effect of Jatropha curcas extract on egg albumin - induced inflammation in Wister Albino Rats

*** Represents $\mathrm{P}<0.001 ; * \mathrm{P}<0.05$ significance values (ANOVA).

NS Normal saline; PC Piroxicam.

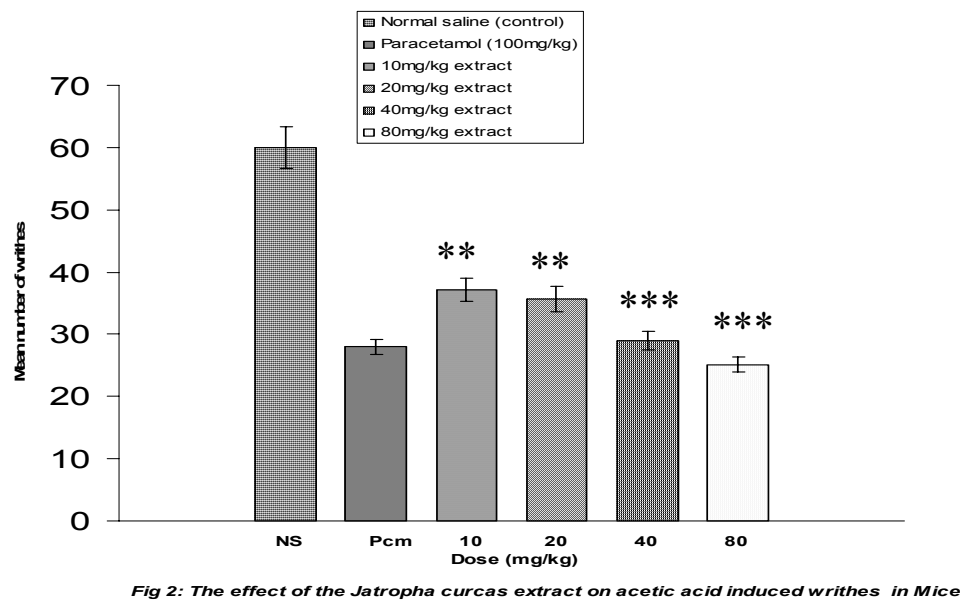

$* * *$ Represents $\mathrm{P}<0.001$ and $* * \mathrm{P}<0.05$ significance (ANOVA)

NS Normal saline; PC Piroxicam.

This study shows that the methanol extract of Jatropha curcas possesses a significant antioedematogenic effect on egg albumin - induced oedema of the paw of albino rats with $\mathrm{P}<0.001$ (ANOVA).This signifies anti-inflammatory activity. The extract was found to be comparable to Piroxicam in activity, especially at higher doses.

Egg albumin- induced inflammation model is a significant predictive test for anti-inflammatory activity (Akah and Nnambie, 1994). These results are an indication that Jatropha curcas can be effective in acute inflammatory disorders.

In acetic acid-induced abdominal writhing which is the visceral pain model (Sawadogo et at., 2006; Gupta et al., 2005), the results show that the extract produced significant analgesic activity at all doses with $\mathrm{P}<0.001$ (ANOVA). The results also show that the extract is comparable to Paracetamol in activity, at similar or higher doses. This analgesic effect of Jatropha curcas can be attributed in part, to its antiinflammatory effect as, in visceral pain model, the precursor releases arachidonic acid through cycloxygenase and prostaglandin biosynthesis which plays a role in the nociceptive mechanism (Franzotti et al., 2002)

This therefore, implies that the inhibition of acute inflammation by these extracts leads to their inhibitory effect on pain development process (Sawadogo et al., 2006).

The phytochemical analysis of the extract revealed the presence of triterpenoids, volatile oils, alkaloids, flavonoids, saponnins and tannins. Alkaloids and flavonoids are well known for their ability to ability to inhibit pain perception (Okwu and Josiah, 2006). 
Flavonoids as anti-oxidants also have antiinflammatory properties due to their inhibitory effects on enzymes involved in the production of the chemical mediator of inflammation (Oweyele et al., 2005).

Finally, this study confirms the efficacy of Jatropha curcas as an analgesic and anti-inflammatory agent, thus gives scientific bases for its traditional uses as anti-snake -bite, anti -cancer and anti- tumor agent. Further study is on the way to isolate, identify and characterize the active constituent responsible for these effects and also to determine the exact mechanism of this action.

\section{REFERENCE}

Akah, P.A; Nnambie, A.I (1994). Evaluation of Nigeria traditional medicine; Plants used for rheumatic (inflammation) disorders. J.Ethnopharmacol 42: 179-182.

Burkill, H.M (1985). The useful plants of West tropical Africa, vol 5.

Franzotti, E.M; Santos, C.V.F; Rodrigues, R.H.V; Mourao, M. R ;Antoniolli, A.R (2002). Antiinflammatory, analgesic and acute toxicity of Sida cardiafolia L. J. Ethno pharmacology. 72: 273-278.

Gubitz G.M (1997). Biofuels and industrial products from Jatropha curcas. Proceedings from symposium held in Managua, Nicara gua, February 1997. Technical University of Graz; Uhlandzasse 8 A.8010 Graz, Australia.

Gupta, M., U.K.; Mazumder, R.; Sambath Kumer, P; Gomathi, Y; Rajeshwar, B.B; Kakoti and V.Tamil Selven, (2005). Anti-inflammatory, analgesic and antipyreticeffects of methanol extract from Bauhinia racemosa stem bark in animal models. J.Ethnopharmacol.,98: 267-273.

Harborne J.B (1998). Phytochemical methods: A Guide to Modern Techniques of Analysis. 3rd ed. Chapman and Hall, London.

Henning R (1996). The Jatropha curcas protection in Mali.Rothkreuzu, D-88138 Weissenber. Germany.
Jones N; Miller J.H (1992). Jatropha curcas: A multipurpose species for problematic sites, The World Bank Washing ton D.C USA.

Odebeyi O and Sofowora (1978). Phytochemical screening of Nigerian medicinal plants L. coydia 41: 41-234.

Okujagu, T.F; Etatuvie S. O; Eze I; Jimoh B; Nweke C; Mbaoji C; (2006). Medicinal Plants of Nigeria; South-west Nigeria. In collaboration with Lagos state Traditional Medicine Board and Botany Department, University of Lagos. $1^{\text {st }}$ ed 2006 1: 20.

Okwu, D.E; Josiah, C (2006). Evaluation of the chemical composition of two Nigerian Medicinal plants. African journal of Biotechnolgy, 5 (4) : 357-361.

Openshaw K (1986). Concepts and Methods for collecting and compilling statistics in Biomas used as Energy. UN statistical office New York USA.

Pattanaik, C; Reddy, S Murthy, M.S (2008). An ethnobotanical survey of Plants used by Didayi tribe of Malkangiri district of Orissa India. Fitoterapia vol 79: (1);67-71

Sofowora, A (1993).Medicinal Plants and Traditional Medicine in Africa.Spetrum books.

Sawadogo, W.R; Boly, R; Lompo, M; Some, N; Lamien, C.E; Guissou, I.P; Nacoulma, O.G (2006). Anti-inflammatory, Analgesic and Antipyretic activities of Dicliptera verticillata . International Journal of Pharmacology 2(4): 435-438.

Trease, G.E. Evans W.C (1989) Trease and Evans Pharmacognosy. A physician guide to Herbal medicine $15^{\text {th }}$ edition:; Ballere tindal London

Veerappan, A., S. Miyazaki and R. Dhananjayan, 2005. Studies on the anti-inflammatory, antipyretic and analgesic properties of the leaves of Aegle marmelos Corr. J. Ethnopharmacol., 96: 159-163. 